\title{
Tomato spotted wilt virus Isolates Giving Different Infection in Commercial Capsicum annuum Cultivars
}

\author{
Bong Nam Chung*, Hak Soon Choi, Eun Young Yang, Jeom Deog Cho, In Sook Cho, Gug Sun Choi and \\ Seung Kook Choi \\ National Institute of Horticultural and Herbal Science, Rural Development Administration, Suwon 440-310, Korea \\ (Received on October 6, 2011; Revised on December 3, 2011; Accepted on December 3, 2011)
}

\begin{abstract}
Tomato spotted wilt virus (TSWV)-infected Capsicum annuum plants were collected from open fields during June to July in 2010. The TSWV isolates were designated as Gneung, Ghang-Kjj, Gchang-Njc, Ghae, and Pap. The nucleotide sequence of the nucleocapsid protein $(\mathbf{N})$ and movement protein $(\mathrm{NSm})$ of the five isolates was determined. The pathogenicity of the five isolates was determined on 14 . annuum cultivars two times by using mechanical inoculation. The five isolates induced different response: Both Gneung and Gchang-Kjj did not infect any of the cultivars in the 2nd trial, while Gchang-Njc, Ghae and Pap infected 11, 6 and 13 of 14 cultivars, respectively. The five isolates also were tested on Solanum lycopersicum breeding line TGC09-71 and three Nicotiana species. S. lycopersicum showed a similar response to the five isolates as did $C$. annuum. Both Gchang-Njc and Ghae infected systemically all three Nicotiana species tested. While both Pap and Gneung did not infect any of the Nicotiana species tested. In conclusion, five TSWV isolates induced different infection spectra in $C$. annuum cultivars, Nicotiana species and an $S$. lycopersicum breeding line. Amino acid sequence analysis of the NSm gene could not support or explain the different infection spectra of the five isolates. This study indicated that various isolates must be used as virus inocula for evaluation of $C$. annuum and $S$. lycopersicum cultivars in breeding programs for TSWV resistance.
\end{abstract}

Keywords : Capsicum annuum, pathogenicity, Tomato spotted wilt virus isolates

Tomato spotted wilt virus (TSWV) was first observed in Australia in 1915 (Brittlebank, 1919), and was later identified as a viral disease in 1930 (Samuel et al., 1930). TSWV has a wide host range of more than 800 species in 82 families and is spread throughout the world. In Korea, TSWV was first observed on paprika plants at Yesan,

\footnotetext{
*Corresponding author.

Phone) +82-31-290-6236, FAX) +82-31-290-6259

E-mail) chbn7567@korea.kr
}

Chungcheong Province in 2004 (Kim et al., 2004). At present, TSWV is widespread in Capsicum annuum crops in Korea.

TSWV have a tripartite RNA genome, composed of the large (L) segment, encoding an RNA-dependent RNA polymerase in negative sense; a medium (M) segment, encoding the NSm protein and the G1-G2 precursor glycoprotein in ambisense orientation; and the small (S) segment, encoding the NSs nonstructural protein and the Nucleocapsid $(\mathrm{N})$ protein also in ambisense orientation (Moyer, 1999). The $\mathrm{N}$ protein encapsidates the virus RNA within the viral envelope (Richmond et al., 1998). NSm is involved in host range determination and symptomatology (Silva et al., 2001), as well as cell-to-cell movement (Kormelink et al., 1994).

Nine species of thrips are reported as vectors of TSWV (Gibbs, 1983). The Western flower thrips (Frankliniella occidentalis) is believed to be a major reason for the incidence of infection by TSWV increasing. However, as pesticides become less available, or less effective, other strategies are needed for crop protection. One such strategy is to use resistant cultivars. Thus, development of resistant cultivars is being conducted by using conventional and non-conventional methods (Cho et al., 1996; Prins and Goldbach, 1998). Accordingly, virus inoculum is needed to screen cultivars for resistance to TSWV. This study was conducted to determine the pathogenicity of TSWV isolates collected from open fields of $C$. annuum crops in Korea for use in screening of breeding lines for TSWV resistance.

C. annuum plants revealing yellowing and necrosis of the shoot tip were collected from the open fields of five places: at Gangneung (Gangwon Province), Gochang (Jeonbuk Province), and Gimhae (Gyeongnam Province) through June and July of 2010 (Table 1). The distance between Gangneung and Gochang is $350 \mathrm{~km}$, between Gochang and Gimhae $230 \mathrm{~km}$ and between Gangneung and Gimhae $250 \mathrm{~km}$. Five $C$. annuum plants collected from different regions were designated as TSWV-Gneung, TSWV-Ghae, TSWV-Gchang-Gchang-Kjj, TSWV-Gchang-Gchang-Njc and TSWV-Pap (Table 1). RT-PCR was used to confirm 
Table 1. Collection of Tomato spotted wilt virus isolates from the open fields of commercial Capsicum annuum and paprika plants

\begin{tabular}{|c|c|c|c|c|}
\hline TSWV isolates & Collection area & Host plants & Symptom & Collection date \\
\hline TSWV-Gneung & Gangwondo Gangneung & C. annuum 'Supermanita' & Yellowing, shoot tip wilt, leaf wilt & 06-28-2010 \\
\hline $\begin{array}{l}\text { TSWV-Gchang- } \\
\text { Gchang-Kjj }\end{array}$ & $\begin{array}{l}\text { Jeonbuk Gochang } \\
\text { Mu-jang-myeon }\end{array}$ & C. annuum 'ldangbaek' & $\begin{array}{l}\text { shoot tip yellowing, leaf necrosis, } \\
\text { fruit ring pattern necrosis }\end{array}$ & 07-09-2010 \\
\hline $\begin{array}{l}\text { TSWV-Gchang- } \\
\text { Gchang-Njc }\end{array}$ & $\begin{array}{l}\text { Jeonbuk Gochang } \\
\text { Gong-um-myeon }\end{array}$ & C. annuum 'Chunhajaeil' & $\begin{array}{l}\text { shoot tip yellowing, leaf and fruit } \\
\text { necrosis }\end{array}$ & $07-09-2010$ \\
\hline TSWV-Ghae & Gyeongnam Gimhae & C. annuum 'Nockwang' & $\begin{array}{l}\text { Double ring, yellowing, mottle, shoot } \\
\text { tip wilt }\end{array}$ & $06-20-2010$ \\
\hline TSWV-Pap & Gangwondo Gangneung & 'Paprika' & shoot tip yellowing & 09-29-2009 \\
\hline
\end{tabular}

that the five $C$. annuum plants were not infected by cucumber mosaic virus (CMV), tobacco mosaic virus (TMV), pepper mild mottle virus (PMMoV) and pepper mottle virus (PepMoV), and they were singly infected by TSWV. The RT-PCR primers used were as follows: CMV forward: 5'-TTAACCACCCAACCTTTGTG-3', CMV reverse: 5'-TCGTCTTTTGAATACACGAG-3'; TMV forward: 5'-CCGTAAAGGGAAAAATAGTAGTAG-3', TMV reverse: 5'-ACGTGCCTGCGGATGTA-3'; PMMoV forward: 5'ATGGCTTACACAGTTTCCAGTG-3', PMMoV reverse: 5'-TTAAGGAGTTGTAGCCCAGGTG-3'; PepMoV forward: 5'-CACATCACCTTGGATGCTTG-3', PepMoV reverse: 5'-ATGCATTTGTACGGGAAGGT-3'; TSWV forward: 5'TGTTGACACAAGGCAAAGAC,-3', TSWV reverse: 5'GCAAGTTCTGTGAGTTTTGC-3'.
Each TSWV isolate was transmitted onto Nicotiana rustica plants by mechanical inoculation using $1 \times \mathrm{PBS}(\mathrm{pH}$ 7.2), for subsequent use as inocula for evaluation on $C$. annuum plants. Single infection of $N$. rustica plants with each corresponding TSWV isolate was confirmed by RTPCR at two weeks after inoculation and the plants were maintained in an insect proof glasshouse. To avoid the generation of defective strains that might occur in successive mechanical passage (Resende et al., 1991), virus inocula plants were prepared every time for each experiments from the isolate source of $C$. annuum plants.

The pathogenicity of the five TSWV isolates was evaluated on 14 commercial $C$. annuum cultivars. To observe the effect of temperature on the response of $C$. annuum plants to infection with TSWV, two trials were conducted: on 31

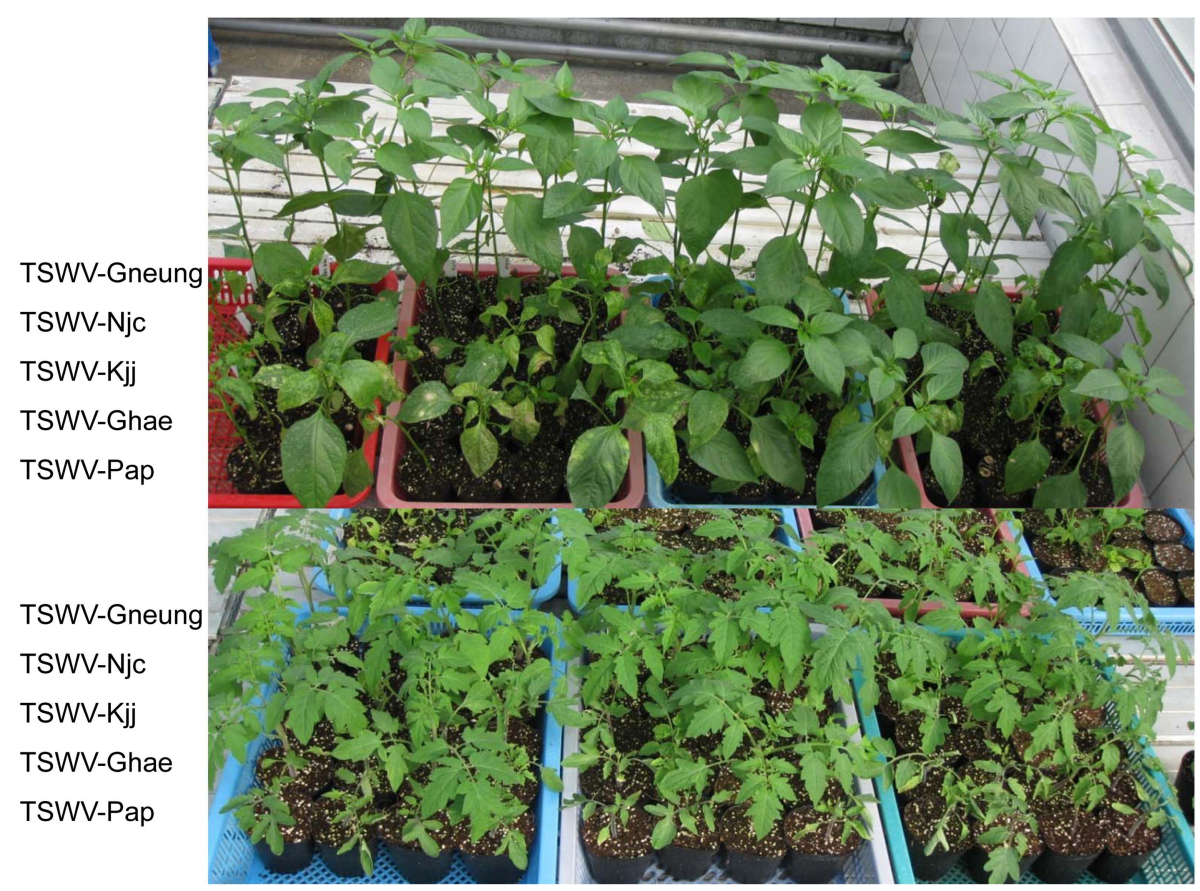

Fig. 1. Evaluation of Capsicum annuum (upper panel) cultivars and Solanum lycopersicum breeding line TGC09-71 (lower panel) for resistance to TSWV isolates Gneung, Gchang-Njc, Gchang-Kjj, Ghae and Pap. In both upper and lower panels, plants positioned in the first, the second, the third, the fourth and the fifth rows from the top of each basket were inoculated with TSWV isolates Gneung, Gchang-Njc, Gchang-Kjj, Ghae and Pap, respectively. Virus was inoculated on Oct. 18, and virus was assayed on Oct. 27-29 by ELISA. 
Table 2. Tomato spotted wilt virus isolates inducing differential responses in Capsicum annuum cultivars (1st trial)

\begin{tabular}{|c|c|c|c|c|c|c|c|c|c|c|c|c|c|c|}
\hline $\begin{array}{l}\text { TSWV } \\
\text { isolates }\end{array}$ & $\begin{array}{l}\text { Super- } \\
\text { umchun- } \\
\text { gna }\end{array}$ & $\begin{array}{c}\text { Ryuck } \\
\text { gangsu } \\
\text { munjang }\end{array}$ & $\begin{array}{c}\text { Jungil } \\
\text { pum }\end{array}$ & $\begin{array}{l}\text { Bigth- } \\
\text { ree }\end{array}$ & $\begin{array}{c}\text { Docbul } \\
\text { wang }\end{array}$ & $\begin{array}{c}\text { Goncho } \\
\text { wang }\end{array}$ & $\begin{array}{c}\text { Noc } \\
\text { wonfood }\end{array}$ & $\begin{array}{l}\text { Nocru } \\
\text { food }\end{array}$ & $\begin{array}{l}\text { Chung } \\
\text { kwang }\end{array}$ & $\begin{array}{l}\text { Saeng } \\
\text { green }\end{array}$ & $\begin{array}{l}\text { Morning } \\
\text { food }\end{array}$ & $\begin{array}{l}\text { Docya } \\
\text { chung } \\
\text { chung }\end{array}$ & & $\begin{array}{l}\text { Chonha } \\
\text { jaeil }\end{array}$ \\
\hline & & & & & & & & & & & & & & \\
\hline & & & & 0.089 & 0.056 & & & & & & & & & 0.099 \\
\hline Jchang-Njc & 987 & & & $\cdot$ & 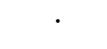 & & & & & & & & & \\
\hline & .950 & & & & & & & & & & & 2.981 & 3.082 & 3.035 \\
\hline Pap & 2.478 & 2.218 & 3.169 & 0.049 & 0.051 & 1.308 & 1.299 & . & 0.047 & 0.761 & 1.215 & 1.186 & 3.056 & \\
\hline
\end{tabular}

${ }^{\mathrm{a}}$ Absorption at $405 \mathrm{~nm}$ by ELISA

$\because$ : not inoculated.

Inoculation method: mechanical inoculation, inoculation period: Aug. 31, investigation period: Sept. 7-13, virus detection: ELISA.

Aug. (temperature inside the glasshouse: $35 \pm 3^{\circ} \mathrm{C}$ ) and on 18 Oct. (temperature inside the glasshouse: $26 \pm 3^{\circ} \mathrm{C}$ ). When two leaves of test plants were fully expanded, crude sap from the five TSWV isolates was rubbed onto the test plants. The crude sap was prepared in $1 \times$ PBS buffer $(\mathrm{pH}$ 7.2). The response was determined at 10 days after inoculation. Virus infection was confirmed by ELISA.

The response of 14 C. annuum cultivars to inoculation by the five TSWV isolates is shown in Fig. 1. In the first trial (31 Aug.), isolate Gneung did not infect any of the $14 C$. annuиm cultivars tested, while both isolates Gchang-Njc and Ghae gave systemic infection in all cultivars tested (Table 2). Isolates Gchang-Kjj and Pap showed different responses on the 14 cultivars. Isolate Gchang-Kjj infected only 'Super-umchungna' and 'Gonchowang' systemically. Isolate Pap infected nine cultivars tested, but not cvs. 'Big three', 'Docbulwang', or 'Chungkwang'. Interestingly, symptom expression on Pap infected cultivars was delayed about for 4 to 5 days in comparison with those cultivars infected with Ghae, and most Pap infected plants showed necrotic double rings on the inoculated leaves (Fig. 2).

In the second trial (18 Oct.), both isolates Gneung and Gchang-Kjj did not infect any cultivars tested, while isolates Gchang-Njc, Ghae and Pap infected 11, six and 13 cultivars, respectively (Table 3 ). In general, in the second trial the tested cultivars showed more resistance to TSWV.

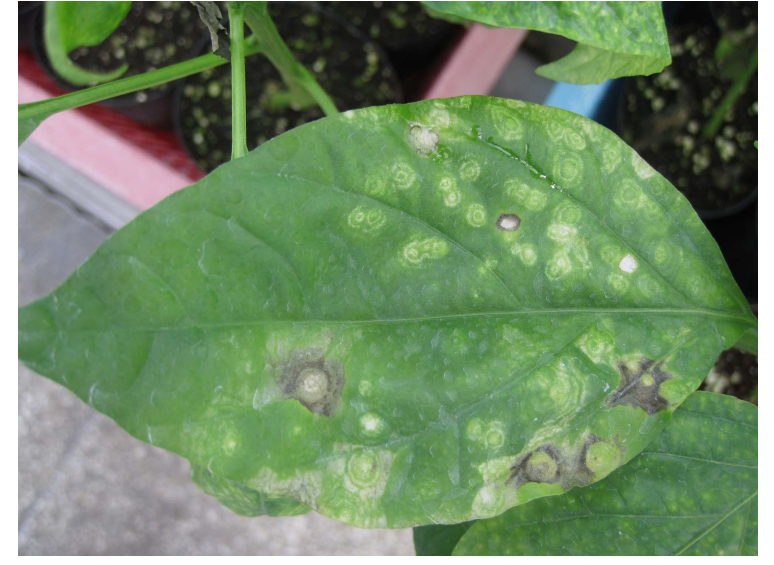

Fig. 2. Necrotic double rings formed on the inoculated leaves of Capsicum annuum cv. 'Super-umchungna' induced by infection with TSWV isolate Pap at 15 days post inoculation.

This phenomenon is consistent with the finding of Roggero et al. (2001), where TSWV resistance, determined by a dominant gene called $T s w$, was broken at high temperature. In this study, the temperature inside the glasshouse in the 1st trial was higher than in the 2nd trial.

In the second trial, five TSWV isolates also were tested on S. lycopersicum segregation line TGC09-71. TGC09-71 is the progeny of crossing lines containing the $T s w$ gene, but

Table 3. Tomato spotted wilt virus isolates inducing differential response in Capsicum annuum cultivars (2nd trial)

\begin{tabular}{|c|c|c|c|c|c|c|c|c|c|c|c|c|c|c|}
\hline $\begin{array}{l}\text { TSWV } \\
\text { isolates }\end{array}$ & $\begin{array}{c}\text { Super } \\
\text { umchun- } \\
\text { gna }\end{array}$ & $\begin{array}{l}\text { Ryuck } \\
\text { gangsu } \\
\text { munjang }\end{array}$ & $\begin{array}{c}\text { Jungil } \\
\text { pum }\end{array}$ & Bigthree & $\begin{array}{c}\text { Docbul } \\
\text { wang }\end{array}$ & $\begin{array}{c}\text { Goncho } \\
\text { wang }\end{array}$ & $\begin{array}{c}\text { Noc } \\
\text { wonfood }\end{array}$ & $\begin{array}{l}\text { Nocru } \\
\text { food }\end{array}$ & $\begin{array}{l}\text { Chung } \\
\text { kwang }\end{array}$ & $\begin{array}{l}\text { Saeng } \\
\text { green }\end{array}$ & $\begin{array}{l}\text { Morning } \\
\text { food }\end{array}$ & $\begin{array}{l}\text { Docya } \\
\text { Chung } \\
\text { chung }\end{array}$ & & $\begin{array}{c}\text { Chunha } \\
\text { jaeil }\end{array}$ \\
\hline & & & & & & & & & & & & & & \\
\hline ichang-Kjj & 086 & & & & & & & & & & & & & \\
\hline & 540 & & & & & & & & & & & & & \\
\hline 1 & 0.225 & & & & & & & & & & & 3.495 & & 0.087 \\
\hline ap & 1.606 & 1.645 & 3.040 & 3.022 & 1.408 & 0.409 & 0.187 & 1.821 & 1.312 & 1.241 & 1.545 & 1.732 & 2.380 & 2.378 \\
\hline
\end{tabular}

${ }^{\mathrm{a}}$ Absorption at $405 \mathrm{~nm}$ by ELISA

Inoculation method: mechanical inoculation, inoculation period: Oct. 18, virus detection period and method: Oct. 27-29. 
Table 4. Evaluation of $S$. lycopersicum breeding line TGC09-71 for resistance to TSWV isolates TSWV-Gneung, TSWV-GchangKjj, TSWV-Gchang-Njc, TSWV-Ghae and TSWV-Pap

\begin{tabular}{lccccc}
\hline \hline \multirow{2}{*}{$\begin{array}{l}\text { TSWV } \\
\text { isolates }\end{array}$} & $\begin{array}{c}\text { No. of plants } \\
\text { infected/inoculated } \\
\text { (ELISA+) }\end{array}$ & \multicolumn{5}{c}{ Symptom rating $^{\mathrm{a}}$} \\
\cline { 3 - 6 } Gneung & $0 / 12$ & 12 & 0 & 0 & 0 \\
Gchang-Kjj & $1 / 12$ & 11 & 0 & 1 & 0 \\
Gchang-Njc & $6 / 12$ & 6 & 0 & 0 & 6 \\
Ghae & $7 / 12$ & 5 & 0 & 0 & 7 \\
Pap & $10 / 12$ & 2 & 0 & 0 & 10 \\
\hline
\end{tabular}

Inoculation period: Oct. 18, investigation period: Oct. 27-29, Virus infection was determined by ELISA.

${ }^{a}$ Symptom rating 0: Not infected, 1: infect without symptom, 2: mild mosaic, 3: stunting and mosaic.

Table 5. Response of three Nicotiana species on infection of TSWV

\begin{tabular}{lccc}
\hline \hline TSWV isolates & $\begin{array}{c}N . \\
\text { debneyi }\end{array}$ & $\begin{array}{c}N . \\
\text { benthamiana }\end{array}$ & $\begin{array}{c}N . \\
\text { occidentalis }\end{array}$ \\
\hline TSWV-Gneung & $-/$ a $^{\mathrm{a}}$ & $-/-$ & $-/-$ \\
TSWV-Gchang-Kjj & $-/-$ & $\mathrm{Mo} / \mathrm{Mo}$ & $\mathrm{Mo} / \mathrm{Mo}$ \\
TSWV-Gchang-Njc & $\mathrm{Ne} / \mathrm{SNe}$ & $\mathrm{Mo} / \mathrm{Mo}$ & $\mathrm{Ye} / \mathrm{Mo}$ \\
TSWV-Ghae & $\mathrm{YS} / \mathrm{Mo}+\mathrm{ye}$ & $\mathrm{Mo} / \mathrm{Mo}$ & $\mathrm{Ye} / \mathrm{Mo}$ \\
TSWV-Pap & $-/-$ & $-/-$ & $-/-$ \\
\hline
\end{tabular}

Inoculation period: Oct. 18, investigation period: Oct. 27-29, Virus infection was determined by ELISA.

a inoculated leaf/upper leaf

Ne: necrosis, SNe: severe necrosis, YS: yellow spot, Mo+ye: mottle with yellowing, Ye: yellowing, Mo: mottle. it is susceptible as a heterozygote. TGC09-71 plants also showed similar response to the five TSWV isolates as did C. annuum (Table 4). Isolate Gneung did not infect any of the plants and isolate Gchang-Kjj infected only one plant, while isolates Gchang-Njc, Ghae and Pap infected six, seven and 10 of 12 plants, respectively.

In the test of three Nicotiana species, both isolates Gchang-Njc and Ghae infected $N$. debneyi, $N$. occidentalis and $N$. benthamiana systemically. Isolate Gchang-Kjj infected only $N$. benthamiana systemically (Table 5). Both isolates Pap and Gneung isolates did not infect any of the three Nicotiana species.

In conclusion, five TSWV isolates induced different infection spectra in C. annuum cultivars, Nicotiana species and an S. lycopersicum breeding line. This study indicated that various isolates must be used as virus inocula for evaluation of $C$. annuum and $S$. lycopersicum cultivars in breeding programs for TSWV resistance.

The sequencing of the $\mathrm{N}$ and NSm genes was done to assess the degree of similarity or difference in the genes likely to contribute to the differences in host range or pathogenicity, as well as the degree of variation between isolates of TSWV and others obtained in previous studies. RNA was isloated from leaf tissue using RNeasy plant mini kit (Qiagen) according to the manufacturer's instructions. The RT-PCR method and primers were the same as in a previous report (Chung et al., 2006). The nucleotide sequences of the $\mathrm{N}$ and NSm genes of the isolates Gneung, Gchang-Kjj, Gchang-Njc, Ghae and Pap were determined using the ABI Prism ${ }^{\mathrm{TM}}$ Terminator Cycle Sequencing

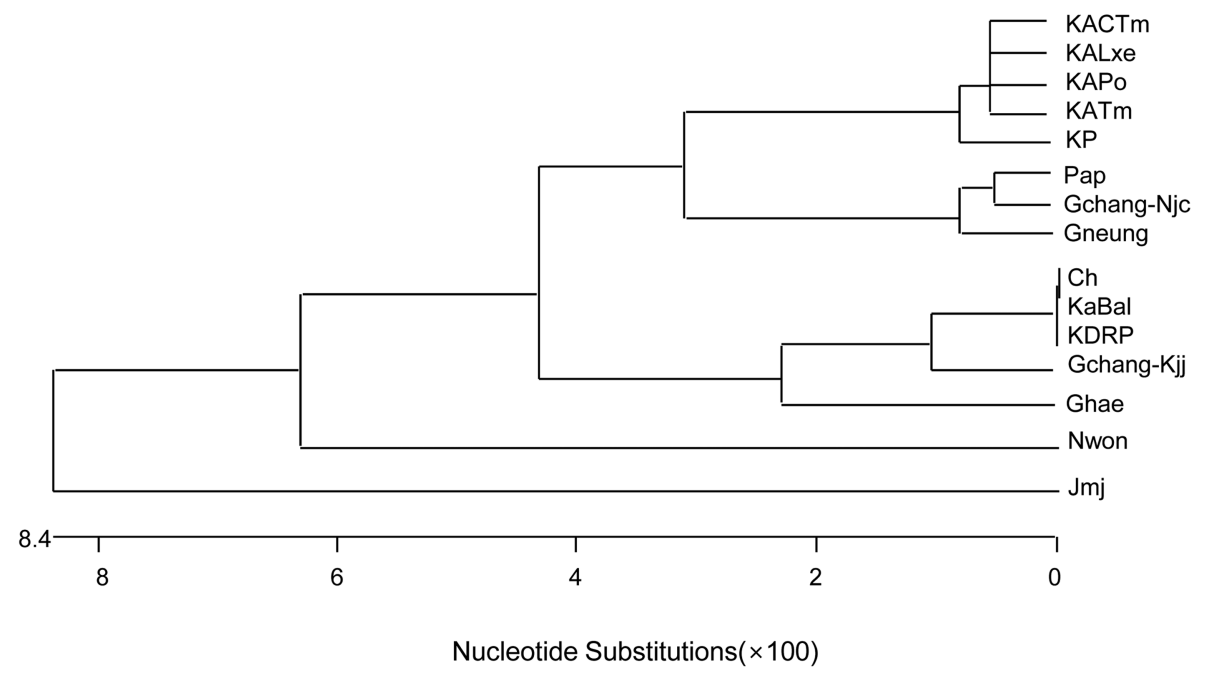

Fig. 3. Phylogenetic relationship of amino-acid sequence of Nucleocapsid (N) gene among Korean TSWV isolates including TSWVGneung, TSWV-Gchang-Gchang-Kjj, TSWV-Gchang-Gchang-Njc, TSWV-Ghae and TSWV-Pap. The scale beneath the tree represents the distance between amino-acid sequences. NCBI GenBank accession numbers are as follows: Ch: DQ453158; KABal: EF195225; KACTm: EF195226; KAIxe: EF195227; KAPo: EF EF195228; KATm: EF195229, KDRP: EF195230; KP: AB190819; Gchang-Kjj: HQ260980; Gchang-Njc: HQ260981; Nwon: HQ260982; Pap: JF730744; Ghae: HQ260977; Gneung: JF730743; Jmj: HQ260979. 
Table 6. The amino-acid sequence percent identity of the N gene among TSWV Korean isolates

\begin{tabular}{|c|c|c|c|c|c|c|c|c|c|c|c|c|c|c|c|}
\hline TSWV & $\mathrm{Ch}$ & KABal & KACTm & KALxe & KAPo & KATm & KDRP & $\mathrm{KP}$ & $\begin{array}{c}\text { Gchang } \\
-\mathrm{Kjj}\end{array}$ & $\begin{array}{c}\text { Gchang } \\
\text {-Njc }\end{array}$ & Nwon & Pap & Ghae & Gneung & Jmi \\
\hline $\mathrm{Ch}$ & & 100.0 & 94.6 & 93.8 & 94.6 & 95.0 & 100.0 & 94.2 & 98.1 & 91.1 & 93.4 & 91.9 & 95.8 & 92.3 & 91.9 \\
\hline KaBal & & & 94.6 & 93.8 & 94.6 & 95.0 & 100.0 & 94.2 & 98.1 & 91.1 & 93.4 & 91.9 & 95.8 & 92.3 & 91.9 \\
\hline KACTm & & & & 99.2 & 100.0 & 99.6 & 94.6 & 98.8 & 92.7 & 93.4 & 93.1 & 94.2 & 92.7 & 94.6 & 91.1 \\
\hline KALxe & & & & & 99.2 & 98.8 & 93.8 & 98.1 & 91.9 & 92.7 & 92.3 & 93.4 & 91.9 & 93.8 & 90.3 \\
\hline KAPo & & & & & & 99.6 & 94.6 & 98.8 & 92.7 & 93.4 & 93.1 & 94.2 & 92.7 & 94.6 & 91.1 \\
\hline KATm & & & & & & & 95.0 & 99.2 & 93.1 & 93.8 & 93.4 & 94.6 & 93.1 & 95.0 & 91.5 \\
\hline KDRP & & & & & & & & 94.2 & 98.1 & 91.1 & 93.4 & 91.9 & 95.8 & 92.3 & 91.9 \\
\hline $\mathrm{KP}$ & & & & & & & & & 93.8 & 94.6 & 93.4 & 95.4 & 93.8 & 95.0 & 91.5 \\
\hline Gchang-Kjj & & & & & & & & & & 90.7 & 92.3 & 91.5 & 95.4 & 91.1 & 90.7 \\
\hline Gchang-Njc & & & & & & & & & & & 89.6 & 99.2 & 90.7 & 98.8 & 88.4 \\
\hline Nwon & & & & & & & & & & & & 90.3 & 92.3 & 90.7 & 93.4 \\
\hline Pap & & & & & & & & & & & & & 91.5 & 99.6 & 89.2 \\
\hline Ghae & & & & & & & & & & & & & & 91.1 & 90.7 \\
\hline Gneung & & & & & & & & & & & & & & & 89.6 \\
\hline
\end{tabular}

NCBI GenBank accession numbers are as follows: Ch: DQ453158; KABal: EF195225; KACTm: EF195226; KAIxe: EF195227; KAPo: EF EF195228; KATm: EF195229, KDRP: EF195230; KP: AB190819; Gchang-Kjj: HQ260980; Gchang-Njc: HQ260981; Nwon: HQ260982; Pap: JF730744; Ghae: HQ260977; Gneung: JF730743; Jmj: HQ260979.

Ready Reaction Kit and ABI Prism 377 Genetic Analyzer (Perkin Elmer, USA), and was registered under the GenBank accession numbers JF730743, HQ260977, HQ260980, HQ260981 and JF730744 for the N gene, and AB650469, AB663306, AB650470, AB650467 and AB650471 for the Nsm gene, respectively.

The amino-acid sequences of the $\mathrm{N}$ gene of the five TSWV isolates were compared to previously reported $\mathrm{N}$ gene amino-acid sequences using the Clustal W method of DNAstar ver. 7. They were grouped into five cluster (Fig. 3): The first cluster contained five Korean isolates including AB190819-KP, a TSWV isolate firstly reported in Korea in 2004; the second cluster consisted of isolates Gchang-Njc, Pap and Gneung; the third cluster contained Gchang-Kjj, Ghae and three other Korean isolates; the fourth and the fifth clusters consisted of isolates Nwon and Jmj alone, respectively. All isolates belonging to the first cluster were the ones isolated in 2005 (Cho et al., 2005; Cho et al., 2009) and were more than $98.1 \%$ identical (Table 6). The percent identity of the $\mathrm{N}$ gene amino-acid sequences between first cluster TSWV Korean isolate KP and each of the isolates Gchang-Kjj, Gchang-Njc, Nwon (unpublished), Pap, Ghae, Gneung and Jmi (unpublished), isolated in 2010 or 2009 (Table 1), ranged from 91.5 to 95.4\% (Table 6). Among the recently collected isolates, Gchang-Kjj showed the closest relationship with 2005 isolates KDRP and KABal (Cho et al., 2005; Cho et al., 2009) and a 2006 isolate Ch (Chung et al., 2006), 98.1\% identity in each case (Fig. 3, Table 6). Based on this result, the nucleotide sequence of the N gene of TSWV Korean isolates has notably varied over the last 7 years since the first emergence of TSWV in Korea. Accordingly, since viruses vary or evolve abruptly, virus inocula used for the evaluation of cultivars for resistance to TSWV should be

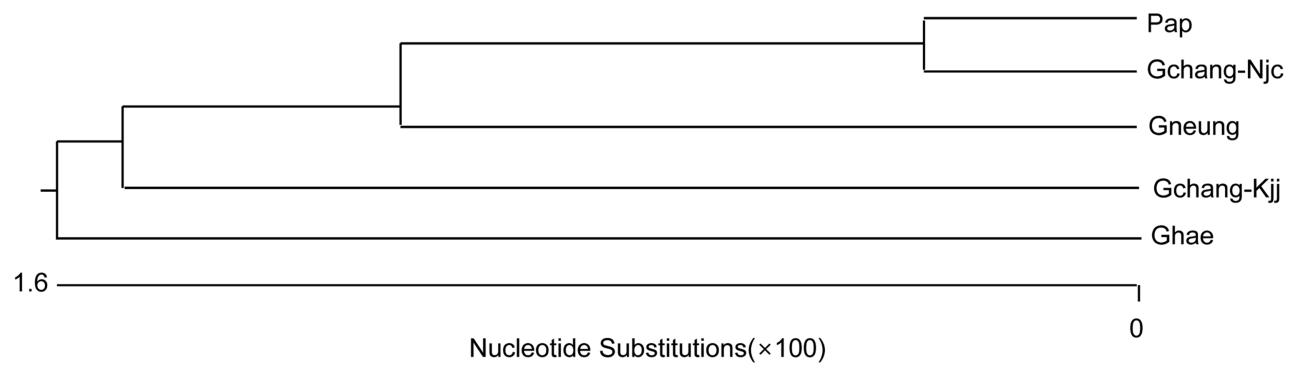

Fig. 4. Phylogenetic relationship of amino-acid sequence of movement protein (NSm) gene among 5 Korean TSWV isolates TSWVGneung, TSWV-Gchang-Kjj, TSWV-Gchang-Njc, TSWV-Ghae and TSWV-Pap. The scale beneath the tree represents the distance between sequences. 


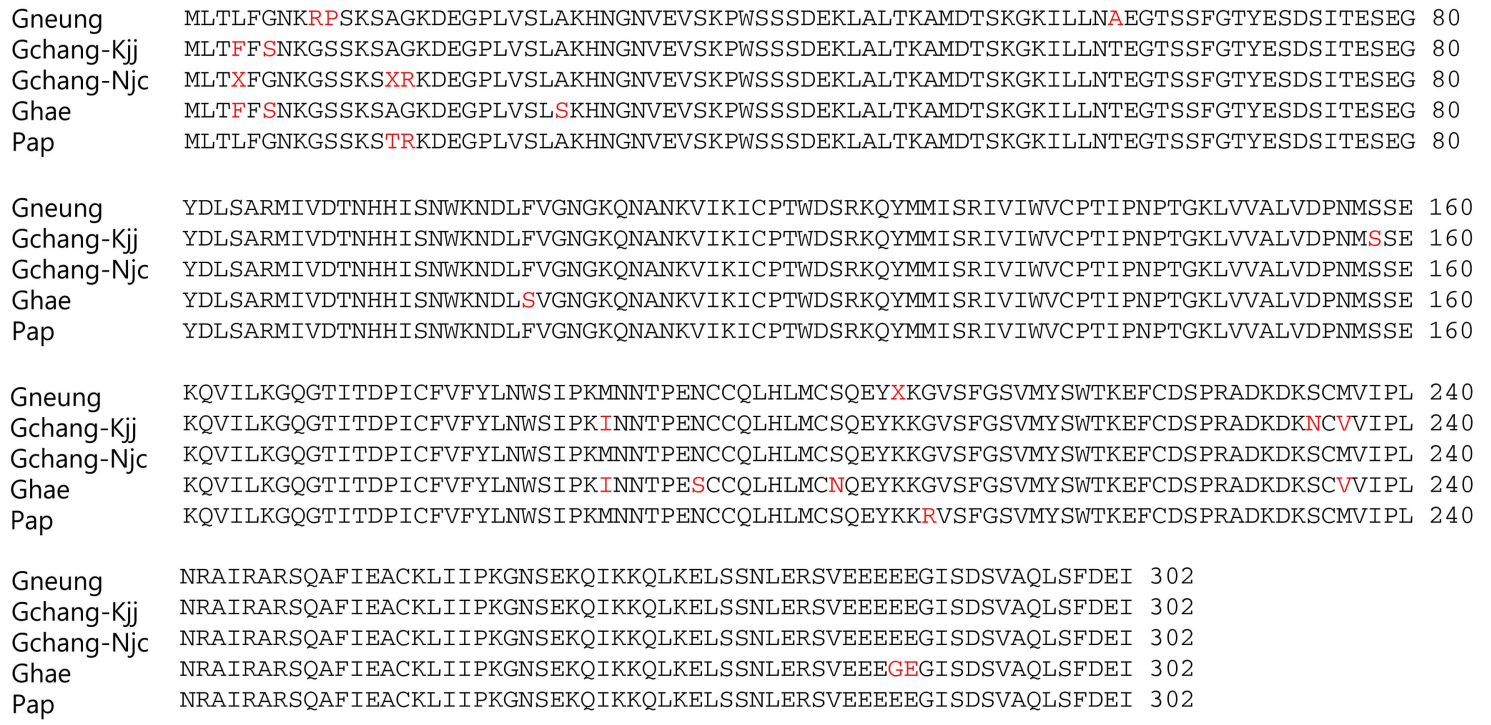

Fig. 5. Alignment of Tomato spotted wilt virus NSm amino-acid sequences. The alignment was carried out by the Clustal W method of DNAstar ver. 7

renewed.

Phylogenetic analysis of the amino-acid sequence of the NSm gene of the five TSWV isolates was conducted using the Clustal W method of DNAstar ver. 7. Isolates Pap and Gchang-Njc were clustered, while the others were more distantly related (Fig. 4). Amino-acid sequence analysis of the NSm gene could not support or explain the different infection spectra of the five TSWV isolates in the present study. Further detailed studies are needed to determine which motifs are involved in host range determination or symptomatology.

\section{References}

Brittlebank, C. C. 1919. Tomato diseases. J. Agr., Victoria, Australia 17:213-235.

Cho, J. J., Chuster, D. M., Brommonschenkei, S. H. and Tanksley, S. D. 1996. Conventional breeding: host-plant resistance and the use of molecular markers to develop resistance to tomato spotted wilt virus in vegetables. Acta Horticulturae 431:367-378.

Cho, J. D., Kim, J. S., Kim, J. Y., Choi, G. S. and Chung, B. N. 2009. Biological characteristics and nucleotide relationships in Korean Tomato spotted wilt virus isolates. Plant Pathol. J. 25:26-37.

Cho, J. D., Kim, J. S., Kim, J. Y., Kim, J. H., Lee, S. H. Choi, G. S., Kim, H. R. and Chung, B. N. 2005. Occurrence and symptoms of Tomato spotted wilt virus on vegetables in Korea. Res. Plat Dis. 11:213-216.

Chung, B. N., Pak, H. S., Jung, J. A. and Kim, J. S. 2006. Occurrence of Tomato spotted wilt virus in Chrysanthemum (Dendranthema grandiflorum) in Korea. Plant Pathol. J. 22:230234.

Gibbs, A. J. 1983. Tomato spotted wilt tospovirus. Plant viruses online. Descriptions and Lists from the VIDE database.

Kim, J. H., Choi, G. S., Kim, J. S. and Choi, C. K. 2004. Characterization of Tomato spotted wilt virus from paprika in Korea. Plant Pathol. J. 20:297-301.

Kormelink, R., Storms, M., Van Lent J., Peters, D. and Goldbach, R. 1994. Expression and subcellular location of the NSm protein of tomato spotted wilt virus (TSWV), a putative viral movement protein. Virology 200:56-65.

Moyer, J. W. 1999. Tospoviruses (Bunyaviridae). In: Encyclopedia of Virology (ed. Webster R., Granoff, A.) pp. 1803-1807. Academic Press, London.

Prins, M. and Goldbach, R. 1998. The emerging problem of tospovirus infection and nonconventional methods of control. Trends Microbiol. 6:31-35.

Resende, R. de O., de Haan, P., de Avila, A. C., Kitajima, E. W., Kormelink, R., Goldbach, R. and Peters, D. 1991. Generation of envelope and defective interfering RNA mutants of tomato spotted wilt virus by mechanical passage. J. Gen. Virol. 72:2375-2383.

Richmond, K. E., Chenault, K., Sherwood, J. L. and German, T. L. 1998. Characterization of the nucleic acid binding properties of tomato spotted wilt virus nucleocapsid protein. Virology 248:6-11.

Roggero, P., Pennazio, S., Masenga, V. and Tavella, L. 2001. Resistance to tospoviruses in pepper. Thrips and tospoviruses: proceedings of the 7 th international symposium on thysanoptera, 105-110.

Samuel, G., Bald, J. G. and Pittman, H. A. 1930. Investigation on 'spotted wilt' of tomatoes. Aust. Council Sci. Ind. Res. Bull. 44:64.

Silva, M. S., Martins, C. R. F., Benzerra, I. C., Nagata, T., de Ávila, A. C., and Resende, R. de O. 2001. Sequence diversity of $\mathrm{NS}_{\mathrm{M}}$ movement protein of tospoviruses. Arch. Virol. $146: 1267-1281$. 